\title{
Impact of some physico-chemical factors of water on the diversity and distribution of Mollusca in Lake Nasser (Egypt)
}

\author{
Soad Saad Abdel-Gawad \\ National Institute of Oceanography and Fisheries, Egypt \\ E. mail: S_abdou_eg@yahoo.com
}

\begin{abstract}
The present study aimed to assess the diversity and distribution of Mollusca under the impact of some physico-chemical variables in Lake Nasser, Egypt. Bottom fauna was sampled for 4 seasons in 2013 and 2 seasons (winter \& summer) in 2015 from the main channel of Lake Nasser and two main of its khurs (Dahmit Khur and Tushka West Khur).The study revealed the predominance of gastropods over bivalves. A total of 10 taxa of freshwater molluscs were recorded, 7 species from Gastropoda and 3species of Bivalvia representing $95 \%$ and $5 \%$ of the total population density of molluscs respectively. Numerically, Valvata nilotica was the most abundant taxa followed by Gyraulus ehrenbergi. Melanoides tuberculata and Bulinus truncatus. Spharium simile and Pisidium pirothi showed less frequent appearance, whereas Cleopatra bulimoides and Corbicula fluminalis were recorded as rare taxa. Relationship between the total number of individuals of molluscs and environmental parameters were determined by Canonical Correspondence Analysis (CCA). The results of analysis revealed a significant correlation between the total number of Mollusca and some environmental parameters, such as dissolved oxygen, $\mathrm{pH}$, depth, transparency. Additionally, Ferrissia sp. was firstly recorded from Lake Nasser.
\end{abstract}

Keywords: Mollusca community, Lake Nasser, diversity, Physico-chemical parameters, CCA.

\section{INTRODUCTION}

Lake Nasser is very vital to Egypt; it provides more than $95 \%$ of the Egyptian freshwater budget. It has a long, narrow shape, in particular of its southern part; Lake Nubia (ElShemy, 2010). Lake Nasser is one of the largest artificial water reservoirs worldwide. The lake was created with the construction of Aswan High Dam $5 \mathrm{~km}$ upstream of Aswan city in Upper Egypt in 1964. It has an irregular shape with many embayments called "Khurs"; 48 lie on the eastern side and 37on the western one (Entz, 1974).The Nile flood comes once a year in late August originating from the Ethiopian highlands. It carries a heavy load of mud consisting of amixture of sand, silt and clay so it is known by high turbidity.

Benthos includes several species of organisms, which cut across different phyla including annelids, arthropods, molluscs. Molluscs are extremely important community of many ecological communities. They prove immensely beneficial both economically and medicinally (Wosu, 2003). Freshwater mollusc communities are important in terms of biodiversity and ecosystem health. They play significant roles in the public and veterinary health and thus need to be scientifically explored more extensively (Supian and Ikhwanuddin, 2002). Freshwater molluscs are useful tools as pollution indicators through assessments of the mollusc community composition and monitoring the heavy metal contamination (Wang et al., 2004; Yang et al., 2005; Jou and Liao, 2006). However, siltation from agriculture, organic pollution, pesticides, heavy metal loading and habitat degradation has threatened the freshwater molluscs. 
These large invertebrates can be considered metabolic reactors because they transfernutrients and energy from water to sediments by filtering, biodeposition of faeces and pseudofaeces, nutrient mineralization (Spooner and Vaughn, 2006) stimulating the production across trophic levels (Vaughn and Spooner, 2006). A lot of researchers have studied the ecology and population dynamics of the gastropods which play an important role in the health of man and his livestock ( Kloos et al., 2001; Ahmed and Elaa, 2003; Karimi et al.,2004; Cañ ete etal.,2004; Mageed, 2006; Kazibwe et al., 2006; Mostafa, 2009). Mollusca are suitable candidates to be used in biomonitoring surveys of Lake Qarun in Egypt (Fishar and Ali, 2006).

These organisms is considered to be affected by environmental factors, like physico - chemical parameters (Garg et al., 2009), availability of food, competition, predator-prey interactions (McMahon et al., 1974; Lassen, 1975; Ofoezie, 1999), substrate architecture (Kershner and Lodge, 1990) and macrophytes (Bronmark, 1985; Costil and Clement, 1996; Ofoezie, 1999).

The objective of present work is to enlist the Mollusca of Lake Nasser perceiving the impact of some physico-chemical variables for a period of one year and half. Further, the results obtained can make an effective contribution to holistic water quality assessmentand the riverine management studies.

\section{MATERIALS AND METHODS}

\section{Area of study}

\section{The Main channel of Lake Nasser:}

Lake Nasser (Fig. 1) has an area of about $5248 \mathrm{~km}^{2}$, a mean depth of 21.5-25.5 $\mathrm{m}$ (maximum $90 \mathrm{~m}$ ) and a width of 8.9 to $18.0 \mathrm{~km}$ at 160 and $180 \mathrm{~m}$ above MSL, respectively. It lies between latitudes $22^{\circ} 00^{\prime}-23^{\circ} 58^{\prime} \mathrm{N}$ and longitudes $31^{\circ} 19^{\prime}-33^{\circ}$ 19`E.(El Serafy et al., 2009). The investigation includes selection of five sectors (Up Stream, Wadi Abyad, Kurusko, Tushka and Abu-Simble) from the main channel of Lake Nasser (Fig.1\& Table1). Fauna was collected from three sites (East, Middle, West) of each sector.

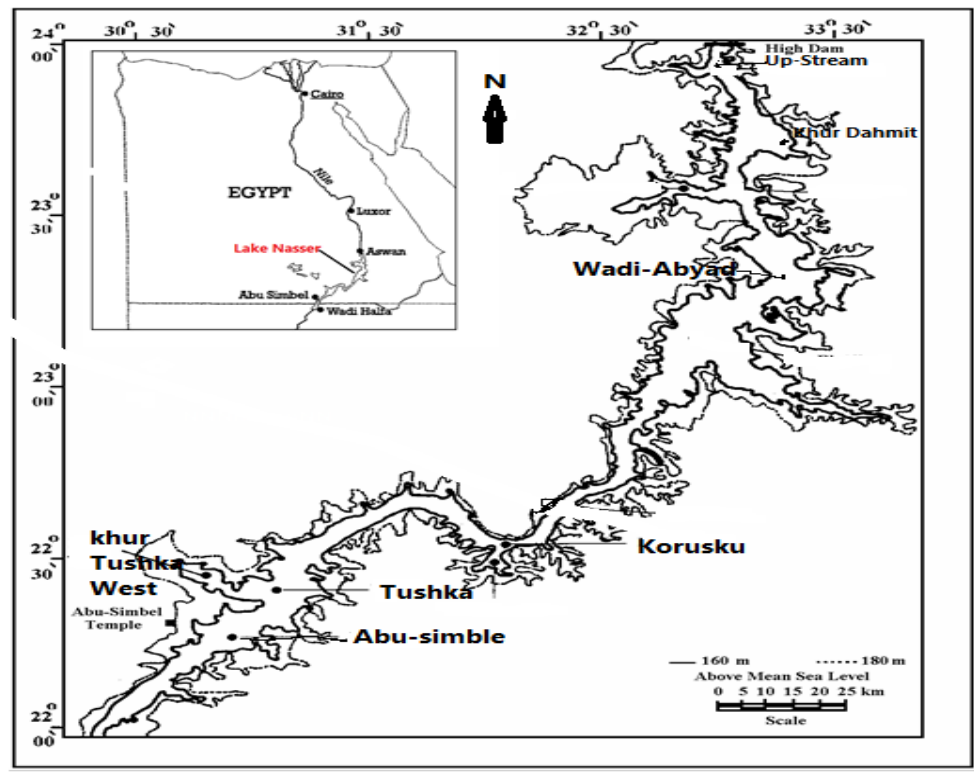

Fig. 1: Map of Lake Nasser showing the selected sectors and khurs of the study. 
Table 1: Latitudes, longitudes and the distance from High Dam for the studied sectors of the main channel of Lake Nasser.

\begin{tabular}{|c|cc|cc|c|}
\hline $\begin{array}{c}\text { Sectors of the main } \\
\text { channel }\end{array}$ & \multicolumn{2}{|c|}{ Lat. } & \multicolumn{2}{c|}{ Long. } & $\begin{array}{c}\text { Distance from High } \\
\text { Dam (Km) }\end{array}$ \\
\hline Up-Stream & $23^{\circ}$ & $56.24^{\prime}$ & $32^{\circ}$ & $51.89^{\prime}$ & 2.9 \\
\hline Wadi-Abyad & $23^{\circ}$ & $20.08^{\prime}$ & $32^{\circ}$ & $56.12^{\prime}$ & 74.3 \\
\hline Kurusko & $22^{\circ}$ & $37.65^{\prime}$ & $32^{\circ}$ & $24.14^{\prime}$ & 167.2 \\
\hline Tushka & $22^{\circ}$ & $36.32^{\prime}$ & $31^{\circ}$ & $55.21^{\prime}$ & 240 \\
\hline Abu-Simble & $22^{\circ}$ & $19.71^{\prime}$ & $31^{\circ}$ & $37.14^{\prime}$ & 268.8 \\
\hline
\end{tabular}

\section{Khurs of Lake Nasser}

Two main khurs of Lake Nasser (Tushka West khur and Dahmit khur) were selected for sampling. On the bases of quantitative and qualitative analysis, the benthic fauna were sampled at many sites covering of each Khur. They are 6 stations from Khur Tushka West (Table 2). Ten stations from Khur Dahmit were sampled (Table 3).

Table 2: Latitudes and longitudes of the sampling stations of Khur Tushka West.

\begin{tabular}{|l|c|c|}
\hline $\begin{array}{l}\text { Stations of Khur } \\
\text { Tushka West }\end{array}$ & Lat. & Long. \\
\hline St.1 & $22^{\circ} 37^{\prime} 50.12^{\prime \prime}$ & $31^{\circ} 41^{\prime} 35.19^{\prime \prime}$ \\
\hline St.2 & $2^{\circ} 36^{\prime} 0.97^{\prime \prime}$ & $31^{\circ} 40^{\prime} 42.09^{\prime \prime} \mathrm{E}$ \\
\hline St.3 & $22^{\circ} 35^{\prime} 49.49^{\prime \prime}$ & $31^{\circ} 46^{\prime} 21.53^{\prime \prime}$ \\
\hline St.4 & $22^{\circ} 34^{\prime} 25.82^{\prime \prime}$ & $31^{\circ} 44^{\prime} 44.18^{\prime \prime}$ \\
\hline St.5 & $22^{\circ} 33^{\prime} 14.10^{\prime \prime}$ & $31^{\circ} 43^{\prime} 17.78^{\prime \prime}$ \\
\hline St.6 & $22^{\circ} 32^{\prime} 1.51^{\prime \prime}$ & $31^{\circ} 47^{\prime} 3.32^{\prime \prime}$ \\
\hline
\end{tabular}

Table 3: Latitudes and longitudes of the sampling stations of Khur Dahmit.

\begin{tabular}{|c|c|c|}
\hline Stations of Khur Dahmit & Lat. & Long. \\
\hline St. 1 & $23^{\circ} 43^{\prime} 12.85^{\prime \prime} \mathrm{N}$ & $32^{\circ} 48^{\prime} 27.64 " \mathrm{E}$ \\
\hline St. & $23^{\circ} 42^{\prime} 50.55^{\prime \prime} \mathrm{N}$ & $32^{\circ} 49^{\prime} 17.07 " \mathrm{E}$ \\
\hline St. 3 & $23^{\circ} 42^{\prime} 32.24^{\prime \prime} \mathrm{N}$ & $32^{\circ} 50^{\prime} 5.93^{\prime \prime} \mathrm{E}$ \\
\hline St.4 & $23^{\circ} 43^{\prime} 54.75^{\prime \prime} \mathrm{N}$ & $32^{\circ} 49^{\prime} 40.58^{\prime \prime} \mathrm{E}$ \\
\hline St.5 & $23^{\circ} 41^{\prime} 50.11^{\prime \prime} \mathrm{N}$ & $32^{\circ} 49^{\prime} 38.03^{\prime \prime} \mathrm{E}$ \\
\hline St.6 & $23^{\circ} 43^{\prime} 12.55^{\prime \prime} \mathrm{N}$ & $32^{\circ} 50^{\prime} 21.36^{\prime \prime} \mathrm{E}$ \\
\hline St.7 & $23^{\circ} 41^{\prime} 54.40^{\prime \prime} \mathrm{N}$ & $32^{\circ} 51^{\prime} 0.57 " \mathrm{E}$ \\
\hline St. 8 & $23^{\circ} 42^{\prime} 34.49^{\prime \prime} \mathrm{N}$ & $32^{\circ} 51^{\prime} 56.98^{\prime \prime} \mathrm{E}$ \\
\hline St.9 & $23^{\circ} 41^{\prime} 35.87^{\prime \prime} \mathrm{N}$ & $32^{\circ} 52^{\prime} 1.63^{\prime \prime} \mathrm{E}$ \\
\hline St. 10 & $23^{\circ} 40^{\prime} 40.05^{\prime \prime} \mathrm{N}$ & $32^{\circ} 51^{\prime} 30.01^{\prime \prime} \mathrm{E}$ \\
\hline
\end{tabular}

\section{Sampling}

Mollusca were collected seasonally during 2013 and 2015 (winter and summer) by collecting bottom samples by the Ekman Grab bottom sampler, covering an area of about $0.03 \mathrm{~m}^{2}$. After collection, the sediment with bottom fauna was washed thoroughly in a small hand net of bolting silk ( $0.5 \mathrm{~mm}$ mesh size $)$. In the laboratory, the molluscs were isolated and picked in and preserved immediately in $10 \%$ neutral formalin solution in polyethylene jars. However, preserved samples of molluscs were identified with the help of Ward and Whipple (1959), Tonapi (1980), Brown (1980), Ibrahim et al. (1999). The abundance of these organisms was calculated as a number per square meter by applying the following formula:

$\mathrm{N}=$ O/A.S x 10,000 (Welch, 1948). Where, $\mathrm{N}=$ no. of macrobenthic organisms (Mollusca) $/ \mathrm{m}^{2} ; \mathrm{O}=$ no. of organisms (Mollusca) counted; $\mathrm{A}=$ area of metallic sampler in square centimeter; $\mathrm{S}=$ no. of samples taken at each station. 
Temperature, $\mathrm{pH}$, dissolved Oxygen and electrical conductivity were measured by Multiparameters Water. Model Senso Direct 150. Transparency was measured by Secchidisc (black and white $20 \mathrm{~cm}$ in diameter). Depth also was measured by EcoSounder, Lowrance Sonar X- 25 model at each site at the same time of sampling. Type of substrate was detected according to Folk (1974). Carbonate $\left(\mathrm{Co}_{3}{ }^{--}\right)$and biocarbonate $\left(\mathrm{HCO}_{3}{ }^{-}\right)$were measured at Chemistry Lab.

\section{Data Analysis}

We analyzed the faunistic and environmental data by means of different multivariate techniques Canonical Correspondence Analysis - using the CANOCO program Version 4.0 (TEa Braak \& Smilauer, 1998). Canonical Correspondence Analysis (CCA) (TEa Braak, 1986) is a multivariate analysis technique developed to relate community composition to known variation in the environment. It is a form of direct gradient analysis where a set of species is related directly to a set of environmental variables. The ordination axes were derived as linear combinations of environmental variables, and individual taxa were related to these axes assuming an unimodal response. The lengths of the arrows in the ordination diagram are proportional to the influence of these variables in species data variation.

\section{RESULTS AND DISCUSSION}

The average values of measured physico-chemical parameters at the stations of the main channel of Lake Nasser and its Khurs are shown in Tables 4 \& 5 respectively. The water temperature ranged between $17.3^{\circ} \mathrm{C}$ and $30.4^{\circ} \mathrm{C}$ in the whole Lake and it followed the air temperature. Temperature has no significant correlation with Mollusca species in thisstudy area. This agrees with Zeybek et al. (2012) who found no significant correlation between temperature and Mollusca species $B$. pseudemmericia, F. pfeiferi, $H$. complanatus and $R$. auricularia.

Table 4: Means and ranges of some physico-chemical parameters at sampling sites of the main channel during the whole period of study. (- = not recorded, $\mathrm{E}=$ East, $\mathrm{M}=$ Middle, $\mathrm{W}=\mathrm{West}$, Temp.= Temperature, E.C. = Electrical conductivity, Trans.= Transparency)

\begin{tabular}{|c|c|c|c|c|c|c|c|c|c|c|}
\hline $\begin{array}{c}\text { Main } \\
\text { channel } \\
\text { sectors }\end{array}$ & & substrate & $\begin{array}{c}\mathrm{DO} \\
(\mathrm{mg} / \mathrm{l})\end{array}$ & $\begin{array}{l}\text { depth } \\
\text { (m) }\end{array}$ & $\begin{array}{c}\text { Temp. } \\
\left({ }^{0} \mathrm{C}\right)\end{array}$ & $\mathrm{pH}$ & $\begin{array}{c}\text { E. C. } \\
(\mathrm{mS} / \mathrm{cm})\end{array}$ & $\begin{array}{l}\mathrm{Co}_{3^{-}} \\
(\mathrm{mg} / \mathrm{l})\end{array}$ & $\begin{array}{l}\mathrm{Hco}_{3}- \\
(\mathrm{mg} / \mathrm{l})\end{array}$ & $\begin{array}{c}\text { Trans. } \\
(\mathrm{cm})\end{array}$ \\
\hline \multirow{3}{*}{$\begin{array}{c}\text { Up } \\
\text { Stream }\end{array}$} & $E$ & Sandy mud & \multirow{3}{*}{5.15} & 32 & $17.6-27.6$ & $7.20-8.47$ & 210 & 0.0 & 122 & 312 \\
\hline & $\mathrm{M}$ & Sandy mud & & 98 & $17.3-25.3$ & $6.84-8.31$ & 209 & 0.0 & 122 & 372 \\
\hline & W & Sandy mud & & 15 & $18-28.8$ & $7.72-8.53$ & 223 & 0.0 & 122 & 316 \\
\hline \multirow{3}{*}{$\begin{array}{c}\text { Wadi } \\
\text { Abyad }\end{array}$} & $E$ & $\begin{array}{l}\text { Gravelly, } \\
\text { sandy mud }\end{array}$ & \multirow{3}{*}{4.7} & 8 & $18.4-29$ & $7.96-8.48$ & 216 & 3.84 & 107.36 & 348 \\
\hline & M & $\begin{array}{l}\text { Gravelly, } \\
\text { sandy mud }\end{array}$ & & 77 & $18-24.8$ & $7.61-7.92$ & 207 & 2.56 & 102.48 & 396 \\
\hline & $\mathrm{W}$ & $\begin{array}{l}\text { Gravelly, } \\
\text { sandy mud }\end{array}$ & & 22 & $18.6-28.8$ & $7.52-8.23$ & 207 & 3.2 & 107.36 & 320 \\
\hline \multirow{3}{*}{ Kurusko } & $\mathrm{E}$ & Muddy sand & \multirow{3}{*}{5.1} & 20 & 18.4- 29 & $7.95-8.47$ & 221 & 0.0 & 107.36 & 206 \\
\hline & $\mathrm{M}$ & Sandy mud & & 74 & $18.3-29.2$ & $7.43-8.37$ & 207 & 3.6 & 102.48 & 225 \\
\hline & W & Muddy sand & & 11 & $19.5-30.4$ & $7.65-8.70$ & 217 & 3.2 & 104.4 & 222 \\
\hline \multirow{3}{*}{ Tushka } & $\mathrm{E}$ & Muddy sand & \multirow[b]{3}{*}{5.58} & 16 & $19.3-28.2$ & $8-8.64$ & 214 & 4.48 & 105.4 & 250 \\
\hline & $\mathrm{M}$ & Sandy mud & & 65 & $18.1-26.5$ & $7.56-8.33$ & 207 & 6.4 & 100.04 & 227 \\
\hline & W & Muddy sand & & 10 & $19.4-27.6$ & $7.67-8.55$ & 215 & 5.12 & 102.5 & 213 \\
\hline \multirow{3}{*}{$\begin{array}{c}\text { Abu } \\
\text { Simble }\end{array}$} & $E$ & Muddy sand & \multirow[t]{3}{*}{6.05} & 18 & $19.1-28.2$ & $7.79-8.81$ & 201 & 3.4 & 87.84 & 180 \\
\hline & $\mathrm{M}$ & Sandy mud & & 56 & $18-28.5$ & $8.21-8.35$ & 205 & 9.6 & 97.6 & 210 \\
\hline & W & Muddy sand & & 5 & $18.2-27.3$ & $8.23-8.30$ & 225 & 0.0 & -- & 260 \\
\hline
\end{tabular}


Table 5: Means and rangesof some physico-chemical parameters at Khur Dahmit and Khur Tushka West during the whole period of study. (Temp.= Temperature, E.C. = Electrical conductivity, Trans.= Transparency)

\begin{tabular}{|c|c|c|c|c|c|c|c|c|c|c|}
\hline & site & substrate & $\begin{array}{c}\mathrm{DO} \\
(\mathrm{mg} / \mathrm{l})\end{array}$ & $\begin{array}{l}\text { Depth } \\
\text { (m) }\end{array}$ & $\begin{array}{c}\text { Temp. } \\
\left({ }^{0} \mathrm{C}\right)\end{array}$ & $\mathrm{pH}$ & $\begin{array}{c}\text { E.C. } \\
(\mathrm{mS} / \mathrm{cm})\end{array}$ & $\begin{array}{l}\mathrm{Hco}_{3}^{--} \\
(\mathrm{mg} / \mathrm{l})\end{array}$ & $\begin{array}{l}\mathrm{Co}_{3--} \\
(\mathrm{mg} / \mathrm{l})\end{array}$ & $\begin{array}{l}\text { Tranc. } \\
(\mathrm{cm})\end{array}$ \\
\hline \multirow{4}{*}{ Dahmit } & 1 & Mud & 7.0 & 21.5 & $19.8-23.9$ & $8.2-8.7$ & 262.8 & 102.48 & 3.2 & 255 \\
\hline & 2 & Mud & 8.2 & 15 & $20.9-25.8$ & 8.5 & 255.8 & 112.24 & 3.6 & 252.5 \\
\hline & 3 & Mud & 6.2 & 22.5 & $20.1-21$ & $8.0-8.4$ & 262.6 & 107.36 & 0.0 & 200 \\
\hline & 4 & Mud & 6.5 & 14 & $20-23.9$ & $8.2-8.5$ & 270.8 & 107.36 & 1.6 & 235 \\
\hline \multirow[t]{6}{*}{ Khur } & 5 & Mud & 7.4 & 14 & $21.7-23.6$ & $8.3-8.4$ & 264.1 & 97.60 & 4.8 & 260 \\
\hline & 6 & Mud & 6.8 & 17 & $20.1-22.5$ & 8.0 & 266.6 & 102.48 & 0.0 & 285 \\
\hline & 7 & Mud & 8.1 & 22 & $21.4-24.8$ & $8.3-8.7$ & 256 & 109.8 & 1.28 & 250 \\
\hline & 8 & Mud & 7.1 & 12.5 & $20.6-22.7$ & $7.5-8.2$ & 264.5 & 107.36 & 1.28 & 283.5 \\
\hline & 9 & Mud & 7.9 & 12 & $22.4-25.6$ & $8.1-8.2$ & 252.5 & 107.36 & 1.6 & 245 \\
\hline & 10 & Mud & 8.2 & 8 & $21.8-25$ & 8.3 & 240.8 & 107.36 & 2.6 & 330 \\
\hline \multirow{6}{*}{$\begin{array}{c}\text { Tushka } \\
\text { West } \\
\text { Khur }\end{array}$} & 1 & Muddy Sand & 7.1 & 18 & $22.2-26.7$ & $8.3-8.7$ & 224.7 & 87.84 & 3.6 & 180 \\
\hline & 2 & Muddy Sand & 8.4 & 9 & $22.1-27.6$ & $8.5-8.7$ & 224.3 & 87.84 & 2.6 & 198 \\
\hline & 3 & Muddy Sand & 8.2 & 12.5 & $21.5-27.7$ & $8.4-8.7$ & 228.5 & 92.72 & 3.6 & 188 \\
\hline & 4 & Muddy Sand & 5.6 & 25.5 & $22.2-23.5$ & $8.0-8.6$ & 225.5 & 92.72 & 4.0 & 160 \\
\hline & 5 & Muddy Sand & 8.2 & 7.5 & $22.4-26$ & $8.3-8.8$ & 230 & 92.72 & 4.8 & 190 \\
\hline & 6 & Muddy Sand & 5.7 & 29 & $21.3-23$ & $8.1-8.5$ & 238.7 & 97.60 & 1.1 & 233 \\
\hline
\end{tabular}

Transparency in the Lake is directly affected by flood. The highest transparency was observed at Up Stream and Wadi Abyad sectors, comparing with the southern ones (Tushka-Abu Simbel) which are affected by the flood. $\mathrm{pH}$ in the lake is slightly alkaline (6.84-8.81). The high $\mathrm{pH}$ values may be attributed to increased photosynthetic activity during the rainy season which reduced the amount of $\mathrm{CO}_{2}$ in the water (Khalil et al., 2013; Abu Bakr and Yakasai, 2015).

The dissolved oxygen (DO) range was $4.7-6.05 \mathrm{mg} / \mathrm{l}$ in the main channel and it was lower than the average DO for khurs (5.6 -8.4 mg/l). This low range of DO in the whole lake may be due to increase of organic matter and decomposition of the organic matter also leads to consumption of DO (Siraj et al., 2010; Abdel Gawad \& Mola, 2014; Abu Bakar and Yakasai, 2015). Kołodziejczyk et al. (2009) mentioned that anoxia might be such a disaster to the molluscs species in eutrophic lakes.

Electrical conductivity (E.C.) ranged between 201 and $270.8 \mathrm{mS} / \mathrm{cm}$ in the Lake and its khurs. Thisrange agrees with the results of Iskaros and El Dardier (2010) in Lake Nasser. The E.C. is affected by water temperature (Gindy \& Dardir, 2008). Thus, the relative increase of E.C. during summer and autumn particularly at the surface was coincided with the high water temperatures which lead to the hydrolysis and redissolution of insoluble salts and subsequently their adsorption onto the lake water.

Fig. 2 shows the percent contribution of different species of Mollusca in the main channel, Khur Dahmit and Khur Tushka West respectively.

The mollusc's ecological features, such as life habit, mode of respiration, sexual reproduction and ability to withstand desiccation, may determine the mollusk community structure in eutrophic lakes.

In the present study, 7 taxa belonging to Gastropoda and 3 taxa belonging to Bivalvia were identified. Of the gastropods, Valvata nilotica Jickeli, 1874, Melanoides tuberculata (Muller, 1774),Cleopatra bulmoides Oliver,1804, Physa acuta Draparnaud, 1805, Bulinus truncatus Audouin,1827 Gyraulus ehrenbergi Beck, 1837 and Ferrissia sp. were recorded. Bivalvia, Spharium simile Say, Pisidium pirothi Jickeliand Corbicula consobrina Muller, 1874 were identified. 


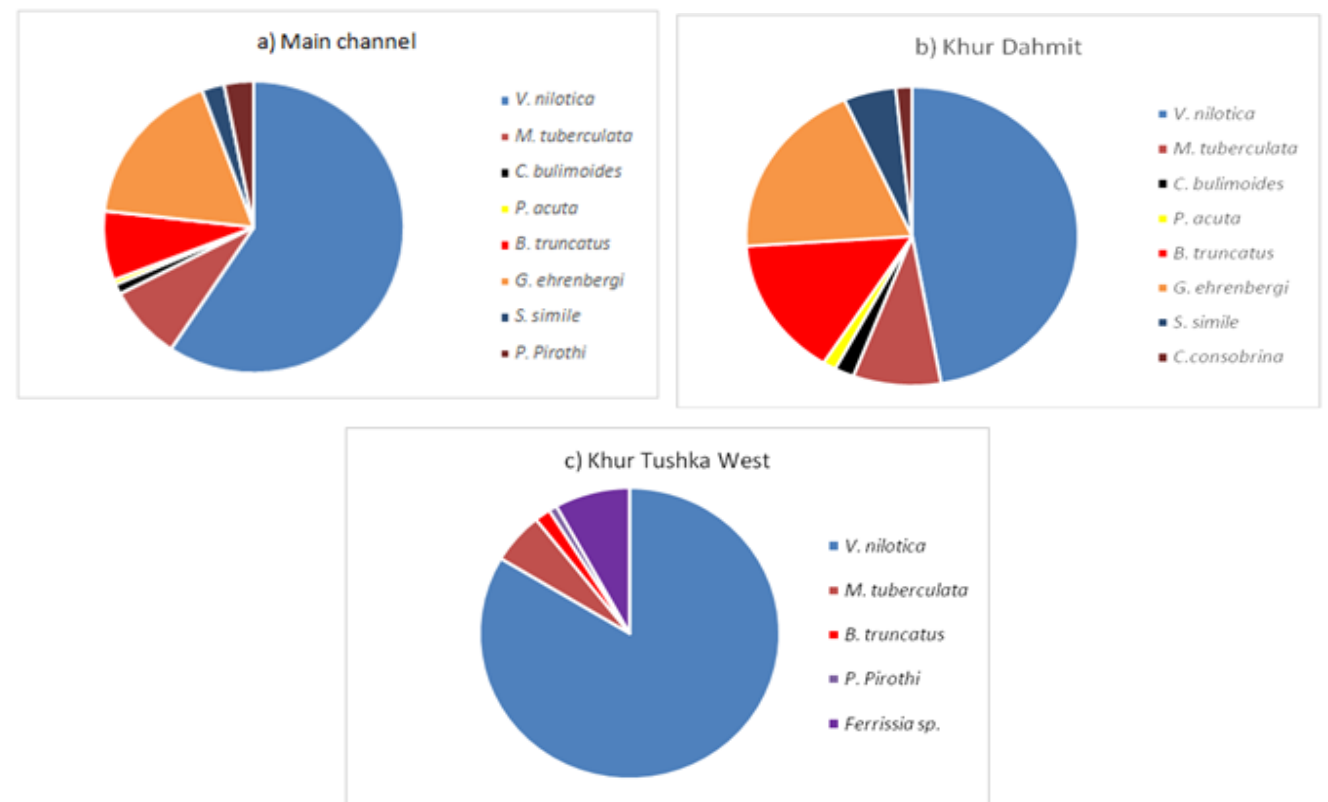

Fig. 2: a,b,c: Pie charts showing percent contribution of different Gastropoda and Bivalvia to the total Mollusca population at the study area.

The mean densities of Mollusca at different sampling sites were differnt from each other. The highest mean densities of Mollusca (348 indivedual $/ \mathrm{m}^{2}$ and 315 indivedual $/ \mathrm{m}^{2}$ ) were observed at Khur Tushka West and Khur Dahmit respectively. This disagrees with Mola and Abdel Gawad (2014) who recorded no living Mollusca at Khur Tushka. In the main channel of the lake, the average density of Mollusca was less than their densities in the khurs; it was 183 indivedual $/ \mathrm{m}^{2}$ in the whole channel during this study. The highest average density (288 indivedual $/ \mathrm{m}^{2}$ ) was observed at Dahmit sector in the main channel, while the lowest $\left(135\right.$ indivedual $/ \mathrm{m}^{2}$ ) was observed at sector Abu Simble (Table 6).

Table 6: The averages of Mollusca density at each site of the main channel and khurs duringthe whole period of study.(E= East, $\mathrm{M}=$ Middle, $\mathrm{W}=\mathrm{West})$.

\begin{tabular}{|c|c|c|c|c|c|c|c|}
\hline $\begin{array}{c}\text { Main } \\
\text { channel } \\
\text { sectors }\end{array}$ & $\begin{array}{l}\text { Sites of } \\
\text { sectors }\end{array}$ & $\begin{array}{l}\text { Mollusca at } \\
\text { sites of main } \\
\text { channel }\end{array}$ & $\begin{array}{c}\text { Mollusca at } \\
\text { sector of main } \\
\text { channel }\end{array}$ & $\begin{array}{c}\text { Sites of Khur } \\
\text { Dahmit }\end{array}$ & $\begin{array}{l}\text { Mollusca } \\
\text { at Khur } \\
\text { Dahmit }\end{array}$ & $\begin{array}{l}\text { Sites of Khur } \\
\text { Tushka West }\end{array}$ & $\begin{array}{c}\text { Mollusca at } \\
\text { Khur Tushka } \\
\text { West }\end{array}$ \\
\hline \multirow{3}{*}{$\begin{array}{c}\text { Up } \\
\text { Stream }\end{array}$} & $E$ & 165 & \multirow{3}{*}{142} & 1 & 0.0 & 1 & 33 \\
\hline & $\mathrm{M}$ & 65 & & 2 & 281 & 2 & 116 \\
\hline & $\mathrm{W}$ & 197 & & 3 & 83 & 3 & 1188 \\
\hline \multirow{3}{*}{$\begin{array}{l}\text { Wadi } \\
\text { Abyad }\end{array}$} & $\mathrm{E}$ & 67 & \multirow{3}{*}{288} & 4 & 0.0 & 4 & 0.0 \\
\hline & $\mathrm{M}$ & 133 & & 5 & 0.0 & 5 & 495 \\
\hline & $\mathrm{W}$ & 660 & & 6 & 149 & 6 & 55 \\
\hline \multirow{3}{*}{ Kurusko } & $\mathrm{E}$ & 396 & \multirow[t]{3}{*}{175} & 7 & 297 & & \\
\hline & $\mathrm{M}$ & 66 & & 8 & 2267 & & \\
\hline & $\mathrm{W}$ & 66 & & 9 & 0.0 & & \\
\hline \multirow{3}{*}{ Tushka } & $\mathrm{E}$ & 98 & \multirow[t]{3}{*}{173} & 10 & 99 & & \\
\hline & $\mathrm{M}$ & 32 & & & & & \\
\hline & $\mathrm{W}$ & 390 & & & & & \\
\hline \multirow{3}{*}{$\begin{array}{c}\text { Abu } \\
\text { Simble }\end{array}$} & $\mathrm{E}$ & 136 & \multirow[t]{3}{*}{135} & & & & \\
\hline & $\mathrm{M}$ & 34 & & & & & \\
\hline & $\mathrm{W}$ & 234 & & & & & \\
\hline
\end{tabular}

The most abundant species in the sampling area throughout the study period were Valvata nilotica, Gyraulus ehrenbergi, Melanoides tuberculata and Bulinus truncates (Fig. 2). 
They appeared in all of the sampling sites, while the others appeared only in some of the stations. The scarce of Pisidiumpirothi and Sphariumsimile (Fig. 3) during this study may be due to the nature of the substrate. These species always distribute in the stony or sandy bottom but the substrate is covered by organic material load in course of eutrophication (Zettler and Daunys, 2007). Anoxia and changing of substrateand fish species composition might be possible explanations why benthic molluscs have been changed and decreased in the eutrophic Lake Daincha (China) (Du et al., 2011). This opinion may explain the decrease and scarcity of Molluscain Lake Nass erduringthis study.

Ferrissia sp. appeared for the first time in Lake Nasser speciallyat Khur Tushka West (Fig. 3). Prosobranchs are often sensitive indicators of water quality because of widespread geographic distribution and obligate contact with aquatic environment (Duft et al., 2007).
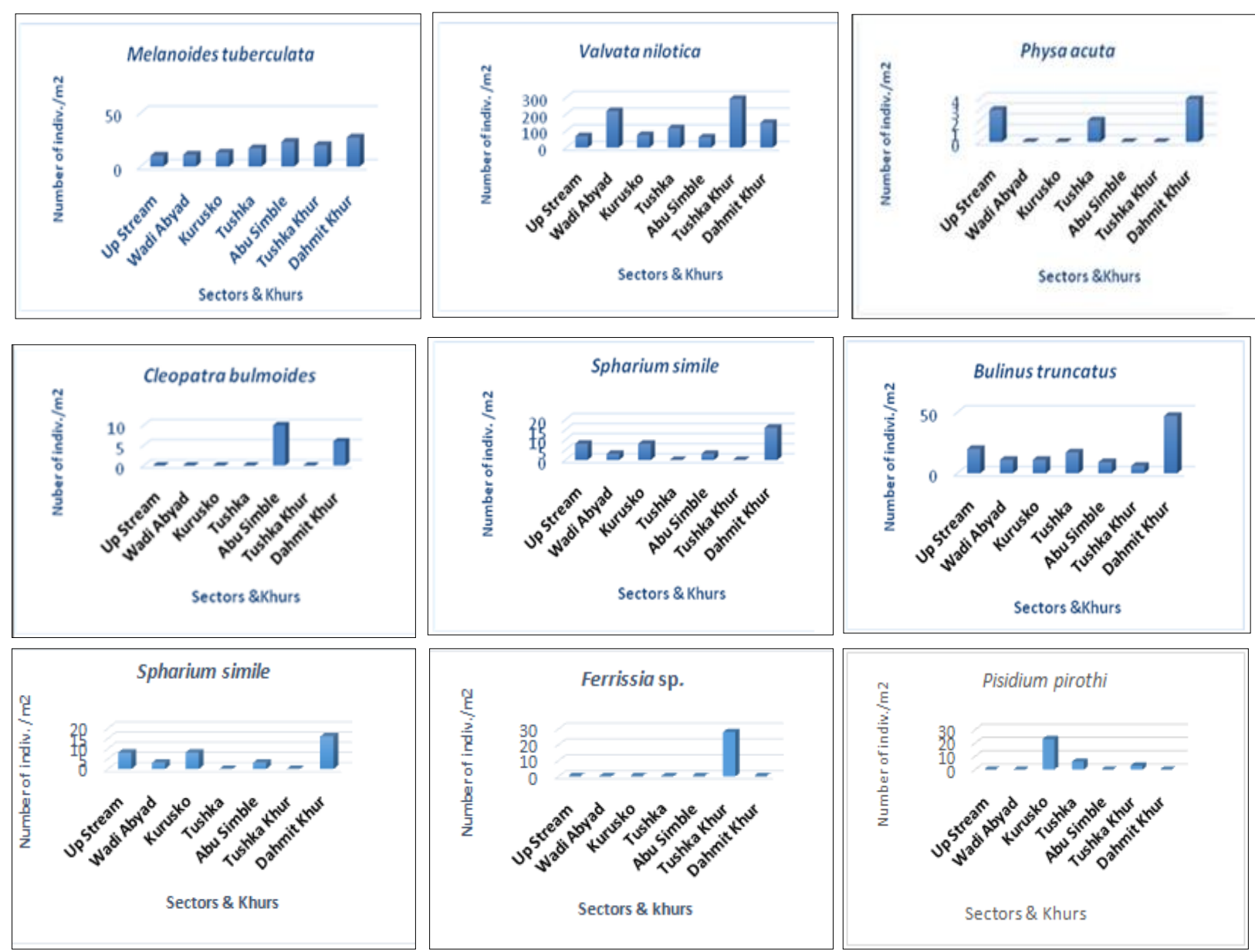

Fig. 3: Distribution patterns of Mollusca (individual $/ \mathrm{m}^{2}$ ) collected from Lake Nasser and its khurs.

Predominanceof gastropodsover bivalves was registeredin this study, which is in agreement with Sharma et al. (2009), Sharma et al. (2013) and Abdel Gawad and Mola (2014) who also recorded similar predominance of gastropods in The Jammu division of J\&K State India, Gho- Manhasan stream, Jammu (J\&K) India, and in the Main Channel of Lake Nasser, Egypt, respectively. 


\section{Canonical Correspondence Analysis (CCA) between Mollusca species and environmental parameters. \\ At Main Channel}

Canonical Correspondence Analysis (CCA) was carried out for analyzing 6 environmental variables with 8 Mollusca species (Fig. 4). Analysis indicated that, the most important factors affecting the distribution of these species were $\mathrm{pH}, \mathrm{E}$. C. and bicarbonate. The CCA biplot diagram has shown that the E. C. has a positive correlation with $P$. acuta, while depth recorded a negative correlation with Cleopatra bulimoides

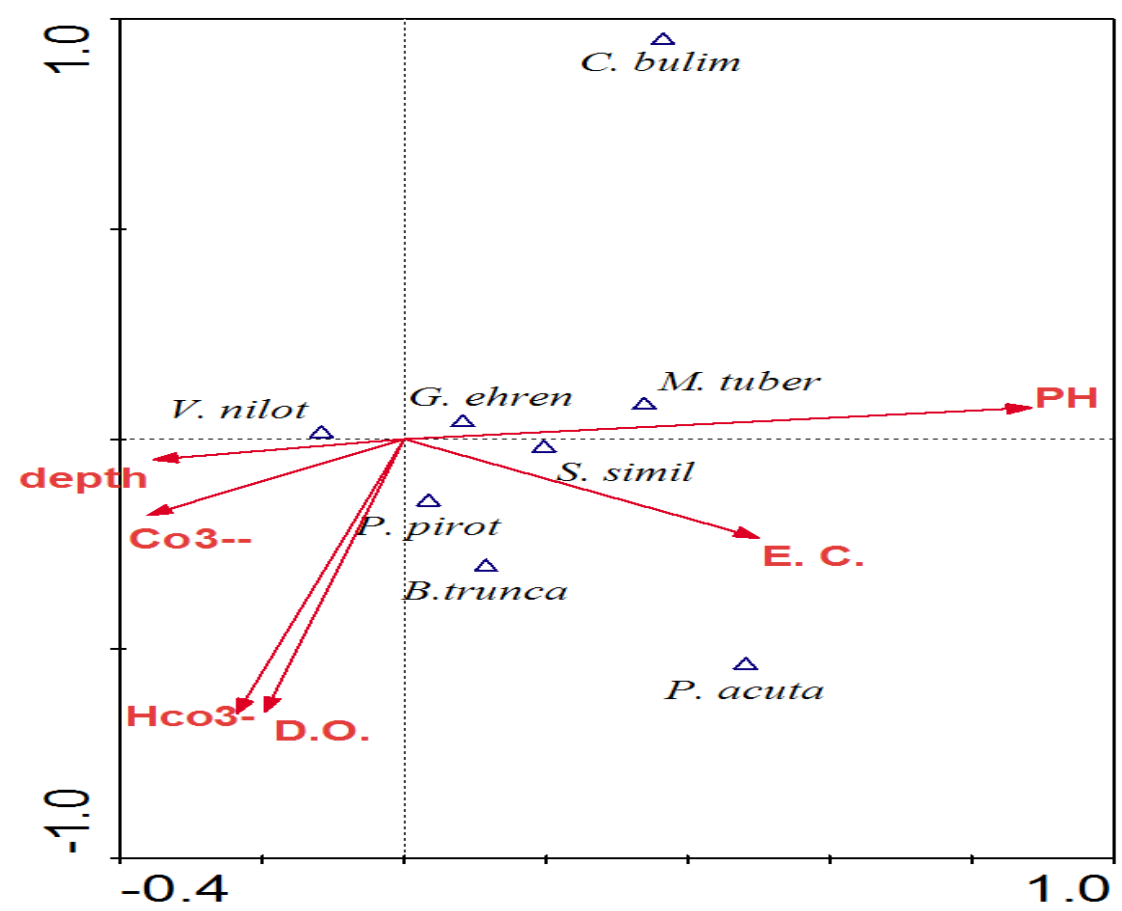

Fig. 4: CCA odination a biplot diagram based on Mollusca species with environmental variables at main channel of Lake Nasser. Species codes (V. nilot. $=$ Valvata nilotica, G. ehern $=$ Gyraulus ehrenbergi, M. tuber.$=$ Melanoides tuberculata, $S$. simil.$=$ Spharium simile, $P$ acuta $=$ Physa acuta, B. trunca $=$. Bulinus truncatus, $P$. pirot $=$ Pisidiumpirothi, C. bulim. $=$ Cleopatra bulimoides

\section{At Khur Dahmit.}

Canonical Correspondence Analysis (CCA) was carried out for analyzing 7 environmental variables with 6 Mollusca species at Khur Dahmit (Fig. (5). Analysis indicated that, the most important factors affecting the distribution of Mollusca species were depth, bicarbonate $\left(\mathrm{HCO}_{3}{ }^{-}\right)$, transparency and $\mathrm{pH}$. The CCA biplot diagram showed that the depth recorded a positive correlation with $S$. simil. but it has recorded a negative correlation with transparency.

At Khur Tushka West

Canonical Correspondence Analysis (CCA) was carried out for analyzing 7 environmental variables with 5 Mollusca species at khur Tushka West (Fig.6). Analysis indicated that,the most important factors affectingthe distribution of Mollusca species were DO, depth, transparency, $\mathrm{pH}$ and carbonate $\left(\mathrm{CO}_{3}{ }^{-}\right)$. The CCA biplot diagram showed that the transparency, E.C. and bicarbonate recorded a positive correlation with Bulinus truncatus. while carbonate recorded a positive correlation with Ferrissi sp. 


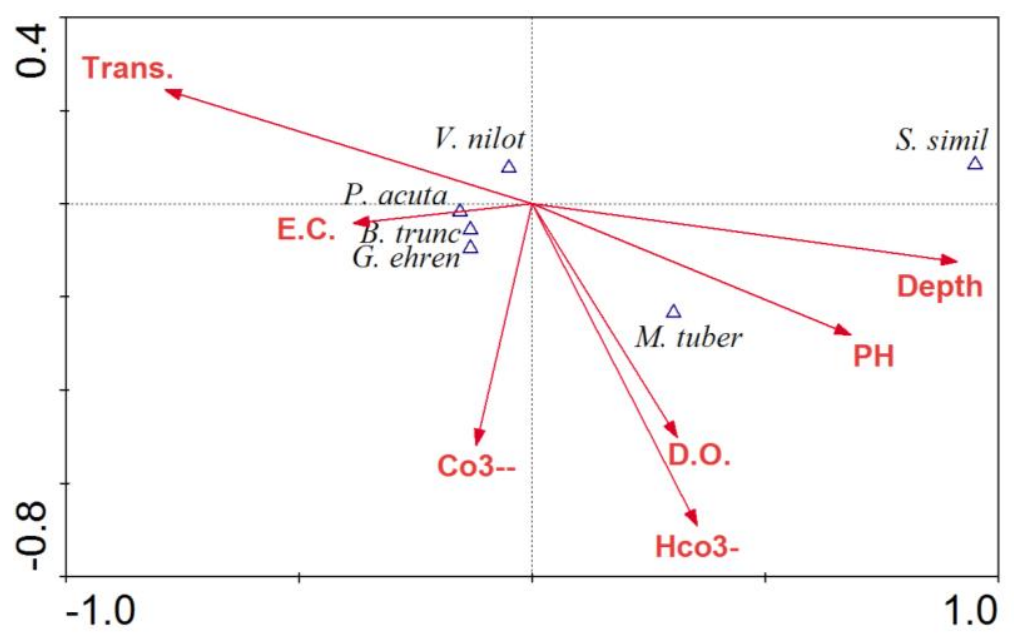

Fig. 5: CCA odination a biplot diagram based on Mollusca species with environmental variables at Khur Dahmit. Species codes ( V. nilot. = Valvata nilotica, G. ehern =Gyraulus ehrenbergi, $M$. tuber.$=$ Melanoides tuberculata,$S$. simil.$=$ Spharium simile, $P$ acuta $=$ Physa acuta, $B$. trunca $=$. Bulinus truncatus.

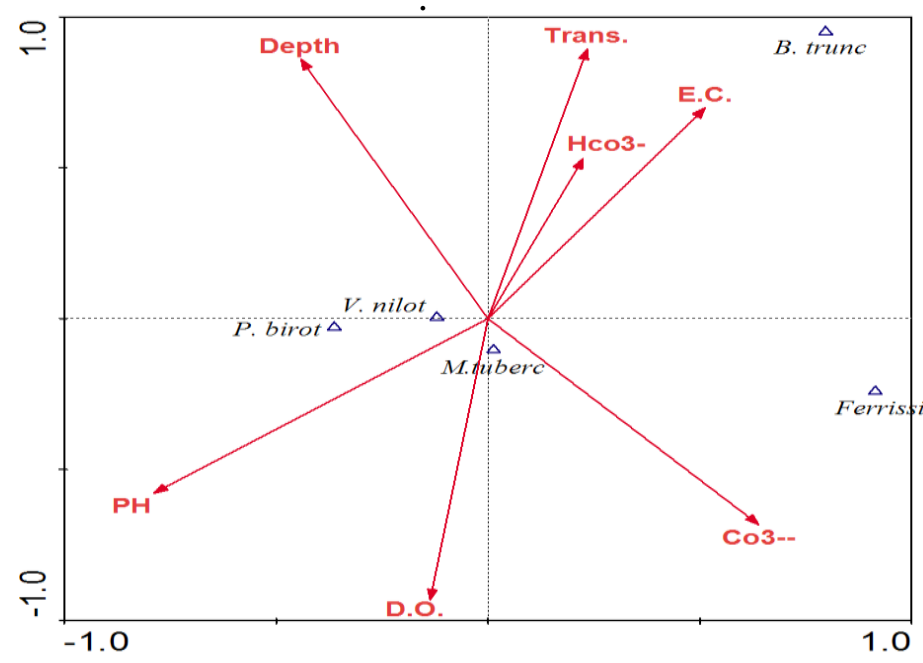

Fig. 6: CCA odination a biplot diagram based on Mollusca species with environmental variables at Khur Tushka West. Species codes (V. nilot. = Valvata nilotica, G. ehern =Gyraulus ehrenbergi, M. tuber. $=$ Melanoides tuberculata, B. trunca=. Bulinus truncatus, $P$. pirot $=$ Pisidium pirothiand Ferrissi. = Ferrissia sp.

Zeybek1et al. (2012) found that some gastropods such as B. pseudemmericia, $F$. pfeiferi, $H$. complanatus, $R$. auricularia were positively correlated with DO values. $B$. pseudemmericia, G. lacustristurca, F. pfeiferi, H. complanatus, $R$. auricularia and T.h. heldreichi were positively correlated with $\mathrm{pH}$ values.Dissolved oxygen levels of the water were a significant parameter for the abundance of especially Prosobranchia species (Y1ldirım, 1999). Some Prosobranchia species could be found in waters with low DO levels (Hart and Fuller, 1974). Şahin and Zeybek (2016) recorded that dissolved oxygen (DO), $\mathrm{pH}$, were the most influential variables on the Mollusca fauna. This information support our results. CCA results of the present study supported also by Okland's (1990) conclusion that $\mathrm{pH}$ is often considered major factor determining the distributions of freshwater snails.

Survival and growth rates of Huliotis irison experimental substrata were significantly greater in deep comparing with shallow habitat (McShane and Naylor, 1995).Depth was a consistently significant factor associated with variation in the postsettlementsurvival of $H$. iris, but a number of other factors covary with depth. 
These factors include wave action, rates of sedimentation and light intensity. Wave action in shallow habitat was insufficientto move the experimental substrata, but it may have caused the dislodgement of recruits (Schiel, 1993).

.It has been concluded, although our knowledge to species ecology is still somewhat limited, results cannot be generalized to many species. However, the levels and the type of such variables differ from species to another. Knowledge of species characteristics can help to increase our understanding of aquatic molluscs and their importance in ecological and biological studies. Further detailed studies on each of these individual parameters and Mollusca are needed

\section{ACKNOWLEDGEMENTS}

I thank all members of Chemistry Lab in Fresh water and Lakes Division, specially Prof. Dr. Mohamed El Shreif for his help in analysis of chemical parameters. Special thanks also to Prof. Dr. Mohamed Reda Fishar for revising this manuscript.

\section{REFERENCES}

Abdel Gawad, S. S. and Mola, H. R.A. (2014). Macrobenthic invertebrates in the main channel of Lake Nasser. E. J. Aqua. Res., 40(4):405-414.

Ahmed, M.H. and Elaa, A.A.A. (2003). Study of molluscan shells and their enclosed bottom sediments in Manzala lagoon, Nile del, Egypt.Bulletin of the Institute of Oceanography and Fisheries, 29: 427-450.

Abu Bakar, M. M. and Yakasai, S. M. (2015). Effect of physico-chemical factors of water on the distributionof macrobenthic invertebrate fauna in the HadejiaNguru wetlands. International Journal of Scientific Engineering and Applied Science (IJSEAS) - 1(4).

Bronmark, C. (1985). Freshwater snail diversity: effects of pond area, habitat heterogeneity and isolation. Oecologia, 67:127-131.

Brown, D. S. 1980: fresh water snails of Africa and their medicalimportance London, Taylor and Francis, 487pp.

Cañ ete, R.; Yong, M.; Sa' nchez, J.; Wong, L.and Gutie' rrez, A. (2004). Population dynamics of intermediate snail hosts of Fasciola hepatica and some environmental factors in San Juan Martinez Municipality, Cuba. Memó' rias do Instituto Oswaldo Cruz, Rio de Janeiro, 99 (3): 257-262.

Costil, K. and Clement, B. (1996). Relationship between freshwater gastropods and plant communities reflecting various trophic levels. Hydrobiologia, 321:7-16.

Du L.-N.; Li Yuan1; Yong, C. X andXing, Y.J. (2011). Effect of eutrophication on molluscan community composition in the Lake Dianchi (China, Yunnan). Limnologica, 41: 213-219

Duft, M.; Schmitt, C.; Bachmann, J.; Brandelik, C.; Schulte-ehlmann, U. and Oehlmann, J. (2007). Prosobranch snails as test organisms for the assessment of endocrine active chemicals - an overview and aguideline proposal for a reproduction test with the freshwater mudsnail Potamopyrgus antipodarum. Ecotoxicology, 16: 169-182.

Elshemy, M. (2010). Water quality modeling of large reservoirs in semi-arid regions under climate change - Example Lake Nasser (Egypt). Dissertation. Abteilung Hydrologie, Wasserwirtschaft und Gewasserschutz am Leichtweiß-Institut fur Wasserbau, Technische Universitat Braunschweig, 234pp. 
El-Serafy, S.S.; Mageed, A.A. and Mola, H.R. (2009). Impact of flood water on the distribution of zooplankton in the main channel of Lake Nasser, Egypt. J. Egypt. Acad. Soc. Environ. Develop., 10(1): 121-141.

Entz, B. G. A. (1974). Limnology. In: "Report on survey to Lake Nasser and Lake Nubia, (1972-1973)

Fishar, M.R. and Ali, M.H.H. (2006). Accumulation of trace metals in some benthic invertebrate and fish species relevant to their concentration in water and sediment of Lake Qarun, Egypt. Egypt. J. Aquat. Rese., 31 (1): 289-301.

Folk, R.L. (1974). Petrology of Sedimentary Rocks. Himplill Publ. Co., Austin, Texas. $182 \mathrm{p}$.

Garg, R.K.; Rao, R.J. and Saksena, D.N.(2009). Correlation of molluscan diversity with physic-chemical characteristics of water of Ramsagar reservoir. India. Int. J. Biodivers. Conserv., 6:202-207.

Gindy, N.N. and El Dardir, M. (2008). Sedimentological and mineralogical studies and organic carbon of Lake Nasser sediments, Egypt. J. Aquat. Res., 34(2):179205

Hart, C.W. and Fuller, S.L.H. (1974). Pollution ecology of freshwater invertebrates. Academic Press, New York:16-28.

Ibrahim, A.M.; Bishai, H.M. andKhalil, M.T.(1999). Freshwater molluscs of Egypt. Department of Nature Protection, Egyptian EnvironmentalAffairs Agency, Cairo, Egypt.

Iskaros, I.A.and El Dardir, M. (2010). Factors affecting the distribution and abundance of bottom fauna in Lake Nasser, Egypt. Nature and Sci., 8 (7): 95-107.

Jou, L.J. and Liao, C.M. (2006). A dynamic artificial clam (Corbicula fluminea) allows parsimonyon-line measurement of waterborne metals. Environ. Pollut., 135: 41-52.

Karimi, G.R.; Derakhshanfar, M. and Paykari, H. (2004). Population density, trematodal infection and ecology of Lymnaea snails in Shadegan, Iran. Archives of Razi Institute, 58: 125-129.

Kazibwe, F.; Makanga, B.; Rubaire-Akiiki, C.; Ouma, J.; Kariuki, C.; Kabatereine, N.B.; Booth, M.; Vennervald, B.J.; Sturrock, R.F. and Stothard, J.R.(2006). Ecology of Biomphalaria (Gastropoda: Planorbidae) in Lake Albert, Western Uganda: snail distribution, infection with Schistosomes and temporal associations with environmental dynamics. Hydrobiologia, 568: 433-444.

Khalil, M.T.; Saad, A.A.; Fishar, M. R., and Bedir, T.Z. (2013).Ecological Studies on macro-benthic Invertebrates of Bardawil Wetland, Egypt. World Environment, 3(1):1-8.

Kershner, M.W.and Lodge, D.M. (1990). Effect of substrate architecture on gastropod-substrate associations. J. N. M. Benthol. Soc., 9(4):319-326.

Kloos, H.; de Souza, C.; Gazzinelli, A.; Filho, B.S.S.; de Costa Temba, P.; Bethony, J.; Page, K.; Grzywacz, C.; Lewis, F.; Minchella, D.; Loverde, P. and Oliveira, R.C.(2001). The distribution of Biomphalaria spp. In different habitats in relation to physical, biological, water contact and cognitive factors in a rural area in Minas Gerais, Brazil. Memo' rias do Instituto Oswaldo Cruz, Rio de Janeiro, 96:57-66.

Kołodziejczyk, A.; Lewandowski, K. and Stan' czykowska, A. (2009). Long-term changesof mollusc assemblages in bottom sediments of small semi-isolated lakes of different trophic state. Pol. J. Ecol., 57 (2): 331-339. 
Lassen, H.H. (1975). The diversity of freshwater snails in view of the equilibrium theory of island biogeography. Oecologia, 19:1-8.

Mageed, A.A.A. (2006). Spatio-temporal variations of zooplankton community in the hypersaline lagoon of Bardawil, North Sinai, Egypt. Egyptian Journal of Aquatic Research, 32 (1): 168-183.

McShane, P. E. and Naylor, J. R. (1995). Depth can Sect post-settlement survival of Haliotis iris (Mollusca:Gastropoda).Journal of Experimental Marine Biology and Ecology,187: 1-12.

McMahon, R.F.; Hunter, R. D. and Russell-Hunter; W.D.(1974). Variation in aufwuchs at six freshwater habitats in terms of carbon biomass and carbon: nitrogen ratio. Hydrobiologia, 145:391-404.

MOla, H. R. A. and Abdel Gawad, S. S. (2014). Spatio-temporal variations of macrobenthic fauna in Lake Nasser khors, Egypt .E. J. Aqua. Res., 40(4): 415423.

Mostafa, O.M.S. (2009). Effect of salinity and drought on the survival of Biomphalaria arabica, the intermediate host of Schistosoma mansoni in Saudi Arabia. Egyptian Academic Journal of Biologica Science, 1(1): 1-6.

Ofoezie, I.E. (1999). Distribution of freshwater snails in the man-made Oyan Reservoir, Ogun State, Nigeria. Hydrobiology, 416:181-191.

Økland, J. (1990). Lakes and snails. Environment and Gastropoda in 1500 Norwegian lakes, ponds and rivers. Universal Book Services, Oegstgeest The Netherlands, $516 \mathrm{pp}$.

Şahin1,S. k.and Zeybek, M. (2016). Distribution of Mollusca fauna in the streams of Tunceli Province (East Anatolia, Turkey) and its relationship with some Physico-chemical ParametersTurkish Journal of Fisheries and Aquatic Sciences, 16: 187-195.

Sharma, K.K; Sharma, S. P. and Sawhney, N. (2009). Distribution and ecology of some fresh water molluscs of the Jammu division of J\&K state. J. Environ. Biosci., 23 (2):179-181.

Sharma, K. K.; Bangotra, K. and Saini, M. (2013). Diversity and distribution of Mollusca in relation to the physico-chemical profile of Gho-Manhasan stream, Jammu ( $\mathrm{J} \& \mathrm{~K}$ ). International Journal of Biodiversity and Conservation, 5(4): 240-249.

Schiel, D.R. (1993). Experimental evaluation of commercial-scale enhancement of abalone Haiiotis iris populationsin New Zealand. Mar. Ecol. Prog. Ser., 97: 167-181.

Supian, Z. and Ikhwanuddin A.M. (2002). Population dynamics of freshwater molluscs (Gastropod: Melanoides tuberculata) in Crocker Range Park, Sabah. ASEAN Rev. Biodiv. Environ. Conserv. (ARBEC), 1-9.

Siraj, S.; Yousuf, A. R.; Bhat, F. A. and Parveen, M. (2010). The ecology of macrozoo-benthos in Shallabugh wetland of Kashmir Himalaya, India. Journal of Ecology and the Natural Environment, 2(5): 84-91.

Spooner, D.E. and Vaughn, C.C.(2006). Context-dependent effects of freshwater mussels on stream benthic communities. Freshwater Biology, 51: 1016-1021.

TerBraak, C. J. F.(1986). Canonical corresponding analysis.a new eginvector technique for multivariat direct gradient analysis. Ecology, 67 (5):1167-1179.

TerBraak, C. J. F. and Smilauer, P. (1998). Canoco reference manual and user guide to Canoco for Windows, software for Canonical community ordination (version 4) centre for Biometry waginengen. 
Tonapi, G.T. (1980). Freshwater animals of India. An Ecological Approach. Oxford and IBH publishing co., New Delhi, Bombay, Calcutta, 341 pp.

Vaughn, C.C. and Spooner, D.E.(2006). Unionid mussels influence macroinvertebrate assemblage structure in streams. Journal of the North American Benthological Society 25: 691-700.

Wang, L.Z.; Liu, Y.D. and Xiao, B.D. (2004). Benthos in the enclosures in the Dianchi Lake.Reservoir Fish. 131: 49-51.

Ward, H.B.and Whipple, G.C.(1959). Freshwater Biology. John Wiley and Sons, Inc. New York, 2:1248.

Welch, P.S. (1948). Limnological Methods. Mc Graw-Hill Book Co., Inc., New York, $381 \mathrm{pp}$.

Wosu, L.O.(2003). Commercial snail farming in West-Africa - A guide. Ap Expess Publishers, NSukka-Nigeria.

Yang, J.; Wang, H.; Zhu, H.Y.; Gong, X.Q.and Yu, R.P. (2005). Bioaccumulation of heavymetals in Anodonta woodiana from Wulihu area of Taihu Lake. Resour. Environ. Yangtze Basin, 14 (3): 362-366.

Y1ldırım, M.Z. (1999). The Prosobranchia (Gastropoda: Mollusca) Species of Turkey and Their zoogeographic distribution, 1. Fresh and Brackish Water. Tr. J. of Zoology, 23(3): 877-900.

Zettler, M.L. and Daunys, D. (2007). Long-term macrozoobenthos changes in a shallowboreal lagoon: comparison of a recent biodiversity inventory with historicaldata. Limnologica, 37: 170-185.

Zeybek1, M; Kalyoncu1, H. and Ertan, O. O. (2012). Species composition and distribution of Mollusca in relation to waterquality. Turkish Journal of Fisheries and Aquatic Sciences, 12: 721-729.

\footnotetext{
ARABIC SUMMARY

تاثير بعض الخواص الفيزيائية والكميائية للمياه على تنوع وتوزيع الرخويات فى بحيرة ناصر مصر

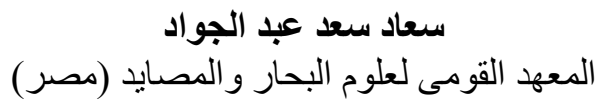

تمت در اسة تاثير بعض العو امل الفيزيائية و الكميائية على تنوع وتوزيع الرخويات فى المجرى الرئيسى لبحيرة

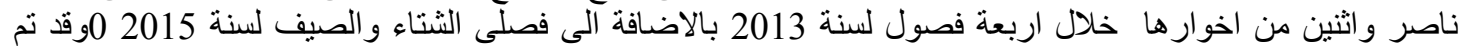

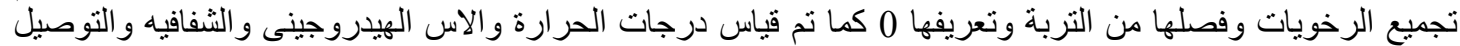

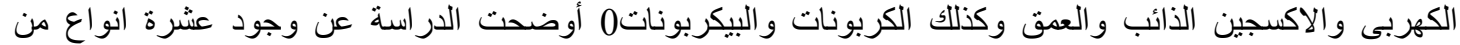

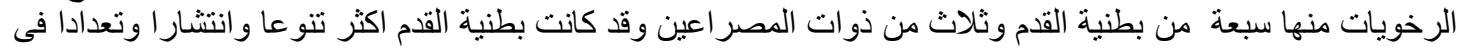

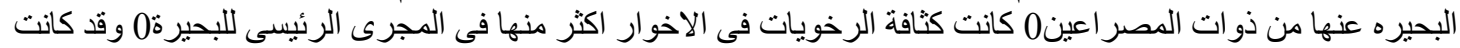
Valvata nilotica Gyraulus ehrenbergi. Melanoides tuberculata, Bulinus truncatus phariumsimile, Pisidium pirothi, Cleopatra bulimoides, Corbicula وانتشار الفى المنطقة بينما كانت و fluminalis

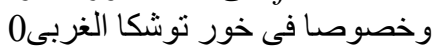

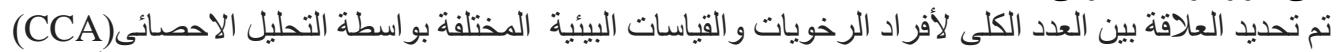

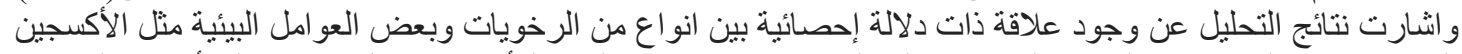

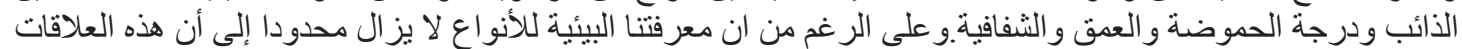

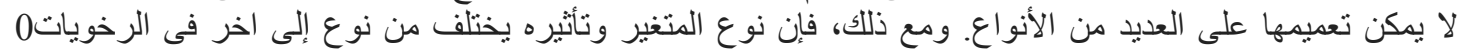

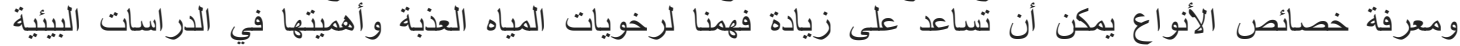
و البيولوجية وهناك حاجة لدراسات تفصيلية أخرى على كل من هذه المعايير منفردة.
} 